\title{
MYBBP1A wt Allele
}

National Cancer Institute

\section{Source}

National Cancer Institute. MYBBP1A wt Allele. NCI Thesaurus. Code C54363.

Human MYBBP1A wild-type allele is located in the vicinity of 17p13.3 and is approximately $16 \mathrm{~kb}$ in length. This allele, which encodes Myb-binding protein $1 \mathrm{~A}$, is involved in the modulation of transcription. 